\title{
Liberación de Alfonsina Storni
}

"La vida, al fin de cuentas, se mide por la muerte", sentenció alguna vez el verso de Alfonsina Storni. Ahora, por esta muerte suya, súbita y querida, podemos medir el dolor de aquella vida frustrada, y la heroica sinceridad de esa gran poesía en que se confesó toda ella.

Nacida para el vuelo, Alfonsina Storni fué una encarcelada en su espacio y en su tiempo. Trajo a ellos una sensibilidad estremecida, un afán infinito de libertad y una como sabiduría congénita del dolor del mundo. Nació -ella misma nos lo dice- "sin blancura":

Cuenta mi pobre madre que, como comprendía, Yo aprendí muy temprano la ciencia de llorar.

Esta sensibilidad aguda maduró pronto en un doble ardor, impeliéndola desde temprano a buscar una perfección vital que dejase por igual satisfechos los sentidos y el alma, "la carne y el sueño".

Pagana tardía en un siglo de hipocresías y de inhibiciones, sostuvo - con el heroísmo biológico que la emparenta a otras poetisas americanas- la legitimidad de ese clamor secreto de la especie. Confesó el "mar oculto" en cada seno de mujer. Emancipándose de la carga ancestral de pudores acumulados en "veinte siglos" de moral mutilada, soñó liberarse a sí misma, y a todas las mujeres en ella, por la vida franca del instinto. El 
amor -pensó helénicamente- no es pecado ni mancha, sino suprema limpieza, es una forma del gran pensamiento creador, un acto de solidaridad con la energía cósmica.

Vivió, pues, el amor con tumultuoso frenesí y lo cantó con una intensidad de palabra incomparable, con un impudor pagano redimido, como la desnudez del niño, por su propia naturalidad.

Pero la "desertora vestal" que así escandalizaba a la ñonez doméstica y a la ñoñez literata de su tiempo, tampoco había de encontrar en la pasión el ritmo sereno, la satisfacción última a que todo su ser aspiraba. El amor de los hombres es fugaz y turbio de engaños; era un amor que hería el alma. Quiso hacer Alfonsina de esta misma herida una fuente de gozo, y como los místicos en su éxtasis transverberado, cantó la fruición del "dulce daño", del veneno bebido en la copa de la carne. iIlusión todavía! La mentira del placer egoísta era demasiado brutal y la fué defraudando "irremediablemente", desilusionándola de la pura sensualidad.

$\mathrm{Y}$ es que, en el fondo más hondo, lo que aquella alma sangrante quería era pagarle su tributo a lo sensual para mejor libertarse. La crítica que ha visto en Alfonsina Storni sólo una erótica ardiente, es harto somera. Lo central en ella era aquella su

... divina locura

De tocar con mis dedos las cosas de la altura.

El instinto, insuprimible, la ceñía a la tierra; quiere liberarse satisfaciéndolo. A las fieras del desierto, símbolos de los apetitos feroces, les acude clamante, en la gran desesperación de su Noche lúgubre: “iLibertadme el alma!" Si el amor de los hombres la deja siempre amargada, es porque no encuentra en ellos la resonancia de su propio espíritu:

Quiero un alma, es un alma lo que busco en la vida.

$\mathrm{Y}$ apela, ya desesperadamente, a Dios mismo, en la desolación de la Media noche: 
i Dios! digo con un grito que me asusta a mí misma:

En tus ojos que se abren mi pupila se abisma

$\mathrm{Y}$ te pones tan blanco que pareces de cera.

El alma, el alma, el alma... Dámela, así muriera!

Fracasó. En vez de luz de estrellas, diéronle a comer tierra. $\mathrm{Y}$ ya sin aquella promesa matinal de la liberación por los sentidos, el mundo todo se le ensombreció. Con la hipocresía de las mujeres y el duro egoísmo de los hombres, vió la vulgaridad implacable de las cosas en torno, de la vida "recortada y vacía". Su sensibilidad se afina dolorosamente para la angustia del mundo:

$$
\begin{aligned}
& \text { tanta lúgubre pena, } \\
& \text { tanta dura cadena,. } \\
& \text { tanto diente de hiena, } \\
& \text { tanta flor que envenena. }
\end{aligned}
$$

Su vida se fué colmando así de frustración. A lo largo de sus tres etapas, el sueño, el presente, el recuerdo - que en alguna medida corresponden a la tonalidad más íntima de sus tres libros principales: El dulce daño, Irremediablemente... y Languidez-, a lo largo de esa busca angustiada de horizontes más libres, sólo ha ido atesorando desengaño. Un momento, parece que va a desembocar en cierto amargo, pero sereno escepticismo. Pero aquella alma ardiente no podía contentarse con negaciones. Era mucho su nativo ímpetu de pureza integral, de plenitud. $\mathrm{Y}$ así, la idea de la muerte como única liberación real, la va rondando insistentemente:

¿No sabes que la muerte es la dulzura jamás gustada en nuestra vida impura?

La contemplación del gran "silencio" se va haciendo más y más fruída en su verso:

¡Cuán amarga es la vida! iY la muerte qué recta!

Ya entre los deliquios pasionales del "dulce daño" tiene el pre- 
sentimiento de su ida pronta, y sueña el estilo sereno de su partida, en "una tarde sin nubes, bajo el límpido sol". ¿Qué había sido, en rigor, toda su vida atormentada, sino un largo ensayo para la muerte, final liberación?

$Y$ así, una tarde, hace unos meses, con su propia mano desató la barca y se echó a bogar

$$
\begin{aligned}
& \text { por los mares negros que tiene la muerte, } \\
& \text { para nunca más. }
\end{aligned}
$$

Se liberó al fin. Dejó una vida que, como nos confesó ella misma en la patética dedicatoria de uno de sus libros, no había conocido la realización de uno solo de sus sueños.

Como fruto inmarcesible de aquella honda raíz de mujer, nos ha quedado una poesía magnífica, estremecida de "carne y de sueño", cruzada, como su vida misma, por el sortilegio de aquellas "tres viejas palabras" que le oyó una noche a la Luna:

Muerte, amor y misterio.

JORGE MAÑACH, Columbia University, 1938. 